\title{
ARE MOUNTAIN AREAS ATTRACTIVE FOR INVESTMENTS? THE CASE OF THE ALPINE PROVINCES IN ITALY
}

\author{
Dario Musolino ${ }^{1}$, Alessia Silvetti ${ }^{2}$
}

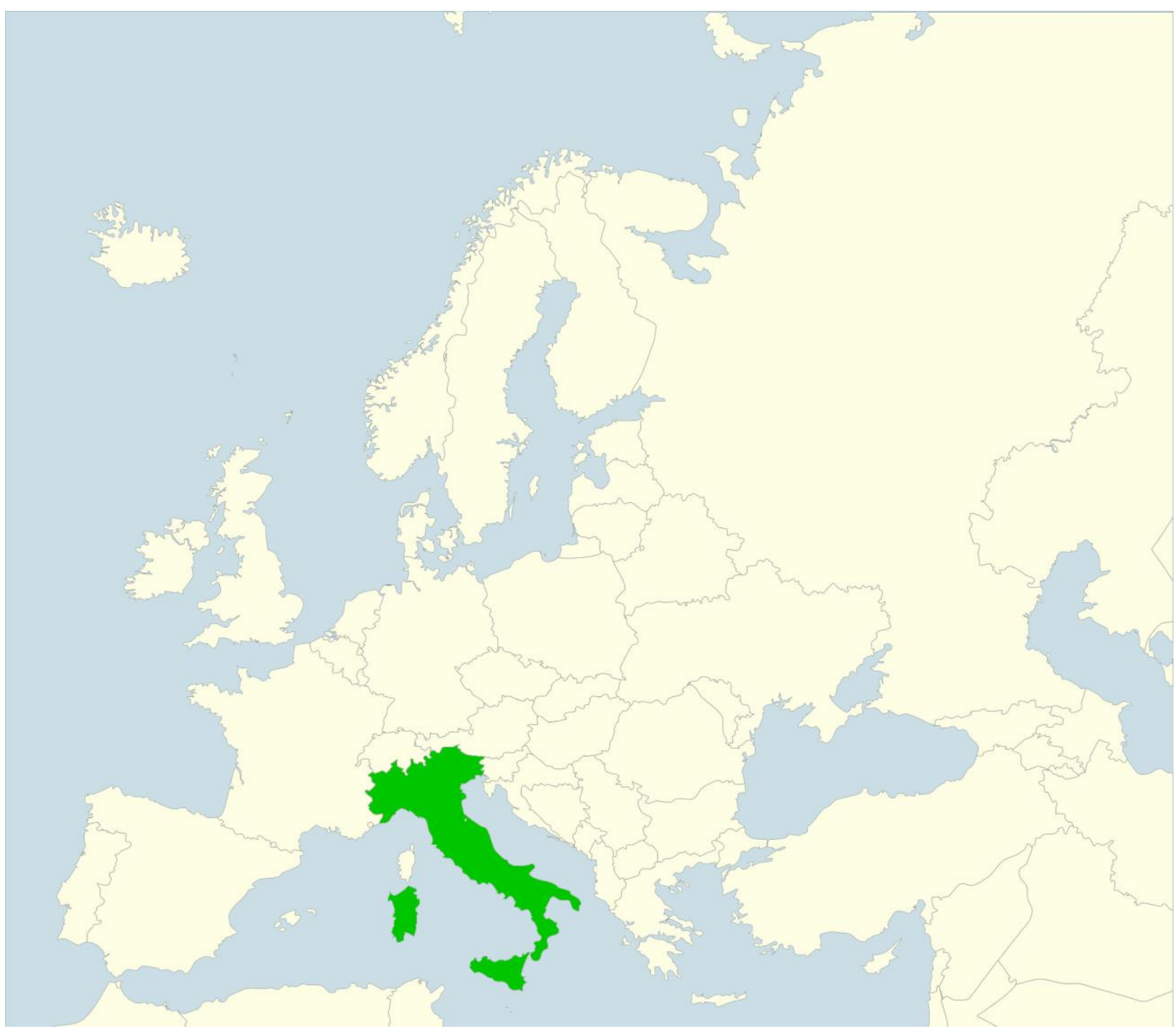

\footnotetext{
1 Dario Musolino, Bocconi University, GREEN (Centre for research in Geography, Resources, Environment, Energy and Networks), Via G. Roentgen 1, 20136 Milan, Italy; \& Università della Valle d'Aosta, Department of Economics and Political Science, Strada Cappuccini 2A, 11100 Aosta, Italy; e-mail: dario.musolino@unibocconi.it, d.musolino@univda.it; ORCID: 0000-0002-8245-0798.

${ }^{2}$ Alessia Silvetti, Università della Valle d'Aosta, Department of Economics and Political Science, Strada Cappuccini 2A, 11100 Aosta, Italy; email: a.silvetti@univda.it.
} 
Abstract: In the increasing territorial competition to attract productive investments in the age of globalization, mountain areas have a role to play, if they wish to find new (exogenous) resources to diversify their economy and to develop sustainably in the future. This means that they have either to be, or to become attractive. Attractiveness for investments is an issue rarely studied with respect to mountain areas. This paper casts light on the attractiveness of the Italian Alpine provinces, using quantitative and qualitative data coming from a research on the stated locational preferences of entrepreneurs in Italy. According to the findings, it is not said that mountain areas are unattractive, due to their characteristics in terms of physical geography and accessibility. Instead, a different perspective on geography itself (Alpine areas bordering with foreign countries), and the role of the government, can make even marginal areas like mountain areas rather attractive for investments. Therefore, policy-makers should identify and strengthen all possible locational advantages that can strengthen the attractiveness of these areas.

Abstract: Nella crescente competizione globale da parte dei territori per attrarre investimenti produttivi, le aree montane hanno un ruolo da svolgere se desiderano trovare nuove risorse (esogene) per diversificare la loro economia e svilupparsi in modo sostenibile in futuro. Ciò comporta che devono diventare attrattive per gli investimenti. L'attrattività per gli investimenti è un tema raramente studiato con riferimento alle aree montane. Questo paper si focalizza sull'attrattività delle province alpine italiane, utilizzando dati quantitativi e qualitativi provenienti da una ricerca sulle preferenze localizzative dichiarate degli imprenditori. Dai risultati emerge che non è scontato che le aree montane siano poco attrattive, date le loro caratteristiche in termini di geografia fisica e accessibilità. Invece, una prospettiva diversa sulla stessa geografia fisica (si tratta di aree confinanti con altre regioni e paesi stranieri) e il ruolo degli enti di governo e della Pubblica Amministrazione, può rendere anche le aree marginali come le aree montane piuttosto attrattive per gli investimenti. Pertanto, i policymaker dovrebbero identificare e rafforzare tutti i possibili vantaggi localizzativi che possono accrescere l'attrattività di queste aree.

\section{Introduction}

Currently, in the age of globalization, one of the main concerns of regions and places, in terms of economic development, is to be attractive. In fact, the growing integration of countries and regions, the increasingly intense international relationships and flows of capital and people, make attractiveness for firms, investments, workers, students, tourists, creative people, etc. an extremely relevant issue (Capello et al., 2011; Capello and Dentinho, 2012; Fratesi and Senn, 2009; Freeman, 2006; UNCTAD, 2017).

In fact, attracting exogenous 'assets' and 'resources' like these has the potential to trigger wide benefits for recipient economies. They can not only have direct economic effects on the regional and local economy and society (think, for example, of the tourist inflows and the university students), but they can enhance and strengthen the territorial capital (Camagni, 2009), and therefore increase the territorial competitiveness of regions and places (Martin, 2006; Annoni and Dijkstra, 2013). The territorial capital is precisely the set of local assets and potentials that build the absolute advantages through which regions and territories can be competitive at the global scale, and which are also nurtured by external relationships and linkages, and by the attraction of drivers ad assets from outside (Camagni, 2002 and 2009). As also said by Martin (2006), one of the first scholars who worked on the conceptualisation of territorial competitiveness, internationalization and openness (in terms of investments, for example) are some of the regional factors which make a region competitive. 
Among several assets that regions can attract, Foreign Direct Investments (FDIs) are increasingly important. They greatly increased at the global scale, together with the phenomenon known as Global Value Chains (GVCs), the model of spatially / internationally dispersed production cycle, through which multinational companies maximise, for each production stage, the locational advantages offered by each country (Baldwin, 2016). From 1990 until now average yearly growth rates of inward FDI flows and stocks were respectively $22 \%$ and $49 \%$ (UNCTAD, 2018).

FDIs, aimed to acquire or to create new companies (greenfield investments or M\&A) have become very important for regional and local development, which apparently cannot be based only on endogenous factors. Italy, for example, the country where endogenous approach took root with the industrial districts model (Becattini, 1989; Bagnasco, 1977; Garofoli, 1991), recently experienced the 'failure' of development strategies and policies based on endogenous development in the Mezzogiorno (Padovani and Provenzano, 2015; Servidio, 2015).

This reflection is also true for rural development. Scholars in this field in fact have realized that the pure and exclusively endogenous way to development (Bosworth and Atterton, 2012; Ward, 2005; Ward and McNicholas 1998) can be hardly achieved, as it is not able to address all the key issues related to peripherality (high transaction costs) and marginality (low demand) (Bosworth and Atterton, 2012; North and Smallbone, 2000). Therefore, in recent years, scholars developed new approaches to rural development, going beyond the endogenous approaches, where "there is an implicit importance of recognition of the importance of extra-local factors" (Bosworth and Atterton, 2012, p. 260). This is the case of the neo-endogenous development (Lowe et al, 1995; Bosworth, 2015; Ray, 2006), the exogenous approach (Bock, 2016), the approach of the social innovation (Neumeier, 2017). Contrarily, they realized that the relationships and linkages with outside are fundamental: for example, think just of the mountain-lowland inter-relations and the inter-regional flows (Dax, 2020). In the past, many scholars saw exogenous investors as potential threats to the balanced and sustainable development model of rural areas. Lowe et al, for example (1998), said that exogenous approach "promote dependent, distorted, destructive and dictated development" (Bosworth and Atterton, 2012, pp. 258). Now, they have clearly realised that globalization changed the wider context, and any region and place, even the most peripheral, is embedded, is part of (and has to be advantageously part of) the plot of the global relationships and linkages.

In the increasingly intense relationships and flows caused by globalization, mountain areas necessarily have to play a role, which means that they have to be, and become attractive, in order to be able to develop in the future. In fact, mountain areas, as much as observed for rural areas, are going through a change of their development model, passing from a model based on a strong specialization on few sectors, to a more diversified model (Bosworth and Atterton, 2012). As mentioned by Dax (2020, p.4), in fact, "contrary to common beliefs, mountains are far from static and when observed over longer timeframes they are in fact highly dynamic and anything but eternal'.

They are abandoning their 'traditional' economic structure based on sectors like tourism and agriculture, due to structural changes at a macro and micro level either on the demand and the supply side, in order to achieve ultimately a more balanced and sustainable development side. There are several examples in this respect: the shift to multi-functionality and diversification in the agricultural sector (McNally 2001; Pfeifer et al. 2009; van der Ploeg et al. 2003); the impact that climate change is having on traditional mountain sectors, like winter tourism (Rixen et al, 2011). Moreover, related again to the environmental conditions, the increasing role of the mountain (and rural) areas as providers of ecosystem services, such as renewable energy, clean water, fresh food products, biodiversity and landscape preservation, recreational opportunities, etc., increasingly demanded by the lowland inhabitants (Dax, 2020). The changes in the entrepreneurial system due to the changing residential and locational preferences of individuals, entrepreneurs or small enterprises, who look for better reduced congestion and better quality of life (Bosworth and Atterton, 2012). Intuitively, all these phenomena take place together with an increasing openness, that is with the increase in the linkages and relationships with the outside (Atterton et al, 2011): "mountain-lowland 
interactions" (Dax, 2020), as aforementioned; import-export flows of primary and manufacturing products, and services joining value chains (Dax, 2020), etc.

This is why the future strategy for the economic development of mountain areas based on sectoral diversification necessarily entails not only nurturing endogenous entrepreneurship, but also opening to and attracting new entrepreneurs, new manufacturing and services firms. Therefore, attractiveness for new and diversified investments is a key current fundamental issue for the future of mountain areas. Then, for all these reasons, considering the evolution of the main approaches to rural and mountain development, it makes sense and it sounds very relevant nowadays to shed light on the attractiveness of mountain areas for external investments.

The literature on this issue is definitely poor. As far as we know, no studies precisely focused on this topic. Attractiveness for investments has been studied mostly at the national and regional scale (Bloningen, 2005; Barba Navaretti et al, 2009; Bentivogli et al 2015; Casi and Resmini, 2010; Daniele and Marani, 2011; Markusen and Venables, 1999; Phelps and Raines, 2003; Santangelo, 2004; Villaverde and Maza, 2012). Almost all these studies are based on the concept of revealed attractiveness: studies based on the concept of perceived attractiveness are less frequent (Meester 2004, Meester and Pellenbarg 2006, Pellenbarg 1985 and 2012, Spilkova 2007). In any case, whatever conceptualisation is assumed, there are no studies focused on the attractiveness of mountain regions.

Attractiveness of mountain regions has been studied for tourism (see for example, for Italy, Baldazzi et al, 2016; Cavallo et al, 2018), but focusing on the inbound tourism, and on the perception of tourists. Neither the locational preferences of services firms interested in investing there, nor the potential investments in mountain regions of firms belonging to the industrial sector, have been an object of specific studies.

The objective of this paper therefore is to explore and study the attractiveness of mountain areas, trying to go beyond the stereotypes, the commonplaces which see the mountain areas as disadvantaged, backward areas, just as "areas of natural constraints" (Dax, 2020); and focusing on the perception by entrepreneurs of the Italian Alpine provinces. The paper is based on the findings coming from a research on the perceived attractiveness by entrepreneurs of Italian regions and provinces, recently conducted in Italy (Musolino, 2015; Musolino et al, 2020; Silvetti, 2017). The paper will try to answer in particular the following research questions:

a)Are Alpine areas in Italy attractive for investments, according to entrepreneurs?

b) Does attractiveness of Alpine areas in Italy change according to the type of entrepreneurs / firms?

c) How can we explain the attractiveness for investments of Alpine areas in Italy? Which location factors (i.e. geographical location, accessibility, agglomeration economies, market size, institutional quality, etc.) affect their perceived attractiveness?

The methodological approach applied to answer these research questions is mixed (Greene et al, 1989), using both quantitative and qualitative methods, within a sequential explanatory research design (Akimowicz et al, 2018). Data, in fact, as we will explain better further on, have been collected at different stages, in order firstly describe extensively the phenomenon under examination (attractiveness of Italian Alpine areas), and secondly to go in depth into the explanation. On a first stage, conducting a survey on entrepreneurs, we collected qualiquantitative data, and we realized the related analyses; on a second stage, conducting direct interviews, we collected additional qualitative data and we realized the related qualitative explanatory analyses.

The structure of this paper is as follows. Section 1 describes the literature on the perception of regions and territories. Section 2 provides key elements about the economy of the Alpine areas in Italy. Section 3 sketches the methodological approach and presents the data collected and used for measuring the perceived attractiveness of Alpine provinces. Section 4 shows the results in a series of tables and choropleth maps mapping the average ratings of Alpine provinces, answering research question a. Section 5 shows the breakdown of the results by 
type of firm and kind of entrepreneur, focusing on a statistical analysis aimed at exploring the explanatory power of these variables (therefore, answering research question b). Section 6 , based on qualitative data collected in the second stage of the same research, focuses on the explanation of the attractiveness of Alpine provinces, presenting and discussing, first, the outcomes of either the content analysis of the responses to the open questions; and, second, the thematic analysis of direct interviews to key informants; this section answers research question 3. Finally, Section 7 draws some concluding remarks.

\section{Literature on perceived attractiveness for investments of regions and territories}

Literature on perceived territorial attractiveness for investments is quite poor, as said above. Most of the studies were conducted at the macro-regional level, while they lack at the local scale (Musolino, 2016). For example, we can find some surveys that concerns either macroregions, such as the Mezzogiorno (Fondazione Nord-Est, 2002; GPF and ISPO, 2005), or some important metropolitan areas in Italy (Osservatorio Marketing Territoriale, 2010), or even peripheral areas in Europe (Ezmale, 2012; Spilanis et al., 2003).

GPF and ISPO (2005) investigated and analysed the perception of the Mezzogiorno as a potential location for investments for the national and international business community. As expected, authors observed that both Italian and foreign entrepreneurs see the Mezzogiorno as a macro-area that considerably differs from the rest of the country. They consider it as a very unfavourable place where to potentially locate their investments, due to the lack of infrastructure, efficient public services and sufficient human capital. Also the evaluation in terms of security (presence of the Mafia organizations) was not favourable. In the surveys on entrepreneurs from North-Eastern Italy (Friuli, Veneto, Trentino Alto-Adige), by Fondazione Nord-Est (2002), the relevance of this negative factor (lack of security) is even more evident, followed by the habits and the culture of Southern people (this latter point, however, is regarded as less important for interviewees who already have business relations with Southern regions). Interestingly, another relevant element emerging from the research by Fondazione Nord-Est is the ability to perceive the regional and local differences within the Mezzogiorno economy. In particularly by highly educated, young and adult entrepreneurs, who lead big firms.

There are then some studies that approached the issue of territorial attractiveness using an extremely limited and focused geographical scope. This is the case, for example, of the study by Politecnico di Milano et al. (2010), in which the perceived attractiveness of Milan was investigated from different perspectives, that is, from the point of view of different actors (business community, tourists, etc.). Alternatively, in a study on Letgallia, a region in Latvia (Ezmale, 2012), the author analysed the perceived attractiveness of the area for residents, tourists, and businesses potentially interested in settling in that territory. There are even some works on peripheral areas like islands, such as the Cyclades in Greece (Spilanis et al., 2003), which approach attractiveness in a multidimensional way, attempting to identify only the most significant location factors.

The only studies focusing on the perceived territorial attractiveness of regions and places for investments are those part of the line of research on the stated locational preferences of entrepreneurs realized in some European countries, the Netherlands, Germany, Czech Republic. This line of research was founded by two Dutch geographers, Piet Pellenbarg and Wim Meester, more than 40 years ago (Meester 2004, Meester and Pellenbarg 2006, Pellenbarg 1985 and 2012, Spilkova 2007).

The feature of this line of research, whose theoretical framework is the behavioural approach to location choice, was the common methodological approach of all these studies on entrepreneurs at the country level (Meester 2004). They were in fact based on a sample survey of manufacturing and services entrepreneurs whose key element was a map of the country depicting 70 locations. Respondents were asked to rate these places as potential locations for their investments on a five-points ordinal scale. 
These studies cast light on the importance of several factors for explaining the perceived attractiveness of regions and places. For example, as concerns studies on the Netherlands and Germany (Meester 2004, Meester and Pellenbarg 2006), the author found that objective explanatory location factors included characteristics such as geographical centrality, high level of accessibility, and the presence of agglomeration effects; locations displaying such characteristics were typically in the "peak area" of the entrepreneurs' mental maps. Differently, peripheral locations, usually devoid of these locational advantages, resulted to be much less attractive for entrepreneurs. Subjective aspects also played an important role, most notably locational self-preferences, in shaping their mental maps. That means "the best place is the one where I already am", revealing special attachments towards particular places that are independent of that place's objective characteristics (Meester 2004). As far as Czech Republic is concerned, research there conducted on foreign entrepreneurs similarly observed the importance of objective location factors like geographical location, as well as other factors such as education level and qualifications of the labour force (Spilkova 2007).

\section{The Italian Alpine areas: key economic characteristics}

The Italian Alpine areas are inhabited by 3.562 million of people (about $5.9 \%$ of the Italian population), and they cover an area of 48,758 square kilometres (about $16 \%$ of the total area of Italy) (FMI, 2017). Population density is 73.1, while in Italy is about 201 (FMI, 2017). They are the widest and biggest, in demographic terms, mountain areas in Italy, compared to Northern, Central and Southern Apennine, and to the mountains in Sicily and Sardinia (FMI, 2017). They had a small demographic decline in recent years in line with the national average, but less than the other Italian mountains (FMI, 2017), and some areas (Trentino Alto-Adige) even showed a positive balance (Istat, 2018a).

The Italian Alpine areas have a remarkable performance in terms of economic development. Data about value added per capita at the provincial scale (Istat, 2018b) show that almost all the Alpine provinces ${ }^{3}$ are in the highest part of the provincial ranking. Bolzano, with about 37.5 thousand euro per capita, ranks even second, after Milan. The only province which lags rather behind is Verbano-Cusio-Ossola. The effect of such level of economic development in the Alpine areas over the Italian average is the high level of activity rate and the low level of unemployment rate (FMI, 2017).

In most of the Alpine areas the key economic specialization is tourism and its related services, like retail trade, restaurants and transport. Tourism is a very important industry, as it comes out from indicators concerning overnight stays and beds per square kilometre, which are very high in the Alps (17.1 in the Alps; 14.2 in Italy; 7.1 in the Apennine) (FMI, 2017). Its contribution to local economic development is considerable: in Bolzano, it they contribute to about $35 \%$ of the provincial value added per capita (Istat, 2018b). Natural and environmental resources, landscape, quality of life, are the key territorial assets that can explain the specialization in this sector, in particularly in winter and green tourism (Baldazzi et al, 2016; Cavallo et al 2018).

However, even manufacturing is important. In particular, in provinces like Bolzano, Belluno, Trento and Sondrio (Istat, 2018b), which are specialized and are competitive in specific sectors, like food, eyewear, mechanics and furniture. The presence of some industrial districts, the high level of $R \& D$ and innovation, related to the presence of important universities, and the proximity to the widest consumer market and to the most dense industrial agglomeration in Italy (Padana Region) can provide an explanation. Nevertheless, some factors, like the low level of transport accessibility, can play a negative role (se Figure 5).

Although such economic development, the actual ability to actually attract foreign investments in the Alpine provinces is rather low, as data at the regional scale by REPRINT-Politecnico di Milano-ICE highlights. In the Aosta Valley, for example, FDIs are extremely scarce (there are

\footnotetext{
${ }^{3}$ Italian provinces correspond to the EU NUTS3 territorial level, and they are totally 110 (while EU NUTS2 territorial level in Italy is represented by 20 regions). Italian Alpine provinces are six, and they are part of five regions: Aosta valley (Aosta valley); Verbania-Cusio-Ossola (in Piedmont); Sondrio (in Lombardy), Trento and Bolzano (in Trentino Alto-Adige) and Belluno (in Veneto).
} 
only 16 foreign-owned companies, with less than 1,700 employees). In Trentino Alto-Adige, the number of foreign-owned companies is higher (almost 490), they employ about 17,300 people and their turnover is about 7.5 million euro: in percentage terms, the share of Italian FDI, compared to other regions, is extremely low (about $1 \%$ ).

\section{Methodological approach and data used for measuring the attractiveness of Alpine provinces}

The data used for measuring the perceived attractiveness of mountain Alpine areas in Italy come from a research on the stated locational preferences of Italian entrepreneurs, leading small and medium firms belonging to a range of industrial and services sectors and branches (Musolino, 2015) ${ }^{4}$.

The main means of this research, conducted within the theoretical and methodological guidelines of the international line of research founded Meester and Pellenbarg mentioned above, was an on-line questionnaire survey, where the key element was an interactive map of Italy showing the spatial units to be rated (administrative regions and provinces, corresponding respectively to Italian NUTS2 and NUTS3 units). The respondents were asked to evaluate each region and province as a possible location for their hypothetic investments ${ }^{5}$ on a five-point ordinal scale, where 1 was "very unfavourable" while 5 was "very favourable" .

All entrepreneurs satisfying the criteria (9985 firms in total) were contacted and requested to participate in the survey ${ }^{7}$, there was no sampling. The number of respondents was 645 , corresponding to a response rate of $6.5 \%{ }^{8}$. The analysis in the following sections is based on the usable response, consisting of the 225 respondents that properly filled out the questionnaire. The main results of the web survey, the perceived attractiveness of Italian provinces, can be seen below, in the choropleth map represented in Figure 1.

\footnotetext{
${ }^{4}$ Entrepreneurs had to satisfy three basic criteria, already applied for the other country-level case studies (Meester, 2004): 1) being capable to make a well-founded judgment on the locational environments in the study area; 2) having an interest, even hypothetical, to evaluate an alternative location; 3 ) having the power to take decisions about the location of the plants (that is to say, who can decide about the location of the firm by themselves). The use of these criteria limited the range of sectors and branches part of the research population. For example, firms belonging to sectors with a strong locational constraint, such as activities bound to the land (mining, agriculture, etc.), were kept out, as they do not have any interest in evaluating alternative and different locations, and therefore they do not satisfy the second criteria.

${ }^{5}$ Respondents evaluated the two geographical levels following a stepwise mechanism: they had to first rate regions and then, eventually/optionally, provinces.

6 The question, accompanying the map, asked respondents to evaluate regions and provinces, in Italian reads: 'Supponga che, per qualsiasi ragione, debba cambiare localizzazione alla sua impresa (o a una unità locale della Sua impresa) all'interno del territorio del nostro paese. Sulla base di questa ipotesi, che valutazione da', come possibile localizzazione, ad ognuna delle aree indicate nella mappa allegata?'. In English: 'Suppose that, for any possible reason, you have to change the location of your firm (or one of the units) within the Italian territory. Given this hypothesis, how do you evaluate each of the areas indicated on the map as possible new locations of your firm?'

7 Database Bureau van Dijk-Aida was the source used to identify firms that constituted the research population (Musolino, 2015).

8 The survey was conducted from January 2010 to July 2011. Due to the time passed, concerns of obsolescence of the data might be obviously raised. The point is that this survey neither is conducted on a regular basis, nor has ever been conducted again since it was done for the first time ten years ago. Therefore, we could not have the possibility to analyse more recent data. Moreover, the novelty and the uniqueness of this kind of analysis in the context of the literature of regional and rural development, according to us is so evident and valuable that make some limitations concerning the data acceptable. Lastly, we have considered that the economy of the mountain areas, although it is going through important changes in the last decades, as said in the introduction, is not as dynamic as in the urban areas; in addition, since the time of the survey, there were no shocks or crises neither in the national nor in the global economy (after the 2008 crisis). Therefore, it is reasonable to assume that the evaluation of the mountain areas as potential locations for investments given by Italian entrepreneurs is still very timely.
} 


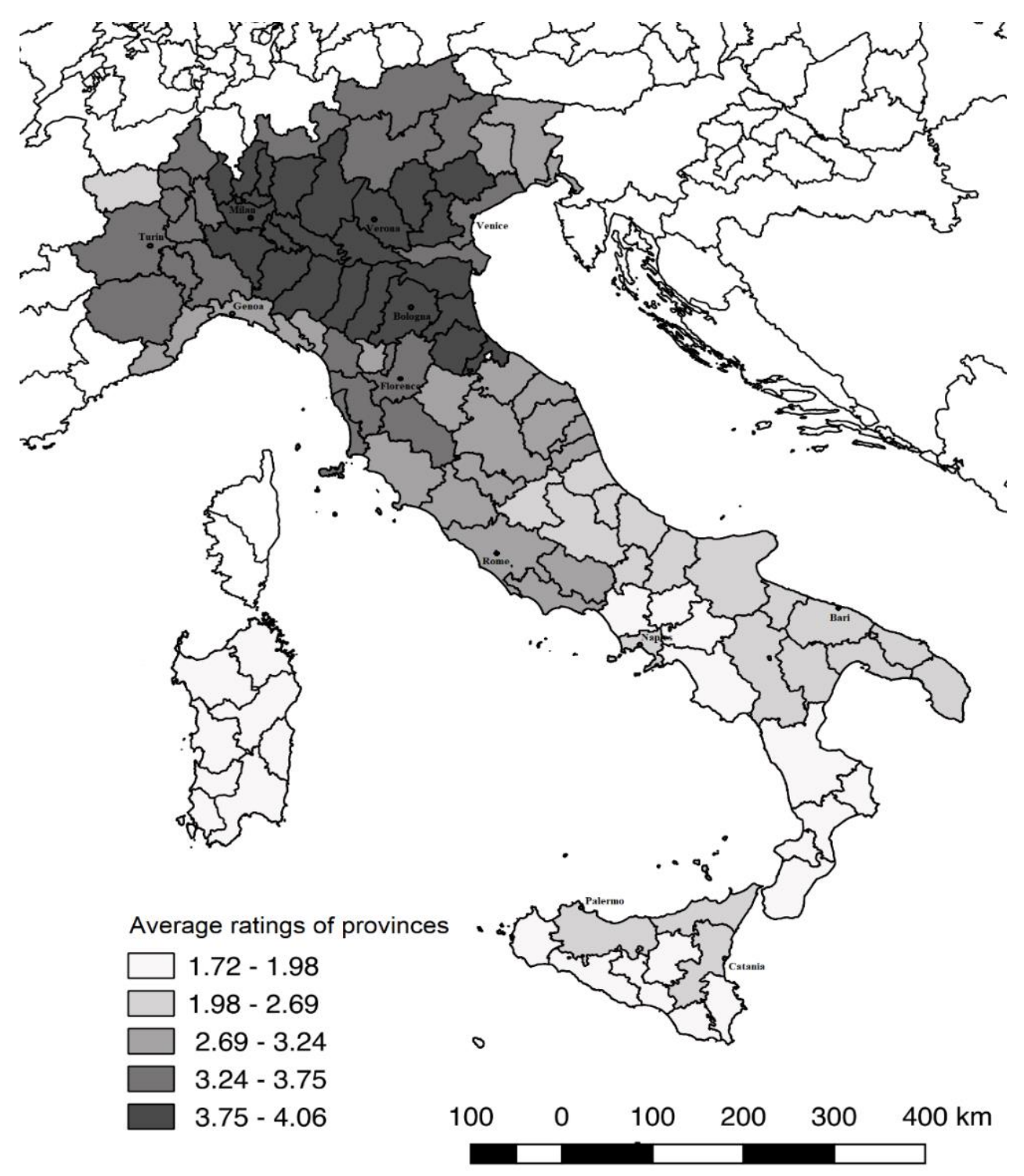

Fig 1. Average rating of Italian provinces (NUTS3). Source: our elaborations on Musolino (2015)

\section{The perception of Alpine provinces by entrepreneurs}

The Alpine provinces have been rated on average 3.33, which is slightly higher than 3 , which is the medium rating (Table 1). The average rating is higher than the Italian average rating, but lower than the average of Northern Italy, and even lower than the average rating of the Padana region, the most attractive area in Italy (and, as mentioned above, the most developed and densely inhabited area in Italy). As you can see from Figure 1 and 2, Alpine provinces surround the Padana region, creating a kind of northern belt of provinces with lower ratings than the core areas. 
Tab 1. Average rating of Italian Alpine provinces (NUTS 3). Source: our elaborations on Musolino (2015)

\section{PROVINCE}

\section{Alpine provinces}

Sondrio

Belluno

Verbano - Cusio - Ossola

Trento

Bolzano

Aosta

Padana region

Northern Italy

Italy
AVERAGE RATING

3.76

3.63

3.33

3.30

2.58

3.78

3.42

2.91

Average ratings differ among the six Alpine provinces. Sondrio, the provincial part of Lombardy, obtains the highest rating, while Aosta, which is itself an administrative NUTS2 region located in the north-western part of the country, obtains the lowest rating, lower than 3 (2.58). In the middle, Trento and Bolzano, the two provinces that are part of Trentino Alto - Adige, and Verbano - Cusio - Ossola, located in Piedmont.

Interestingly, Table 2, where the average rating of the Alpine provinces is compared with the average rating of the respective five administrative regions, casts light on two points. First, the former group always obtain a rating lower than the latter one, except for the case of Valle d'Aosta, where precisely the provincial and regional territory coincide. This allows us to deduce that the other provinces part of the administrative region ('not Alpine provinces'), characterized by higher centrality and lower marginality, enjoy a higher level of perceived attractiveness compared to the mountain ones.

Secondly, the ranking of the Alpine provinces follows the ranking of the respective regions. This means that, in the perception of areas such as the Alpine ones, the wider regional scale might play an important role. Then, when a region receives a positive evaluation, and therefore occupies a prominent place in the mental maps of entrepreneurs, this might be reflected "in cascade" on the territories that are part of it, which therefore to a certain extent "live on reflected light'. This might be one of the reasons why, provinces such as Sondrio and Belluno, located respectively in the two of the three most attractive regions of Italy, turn out to be the most attractive mountain areas of the Alpine Arc. 


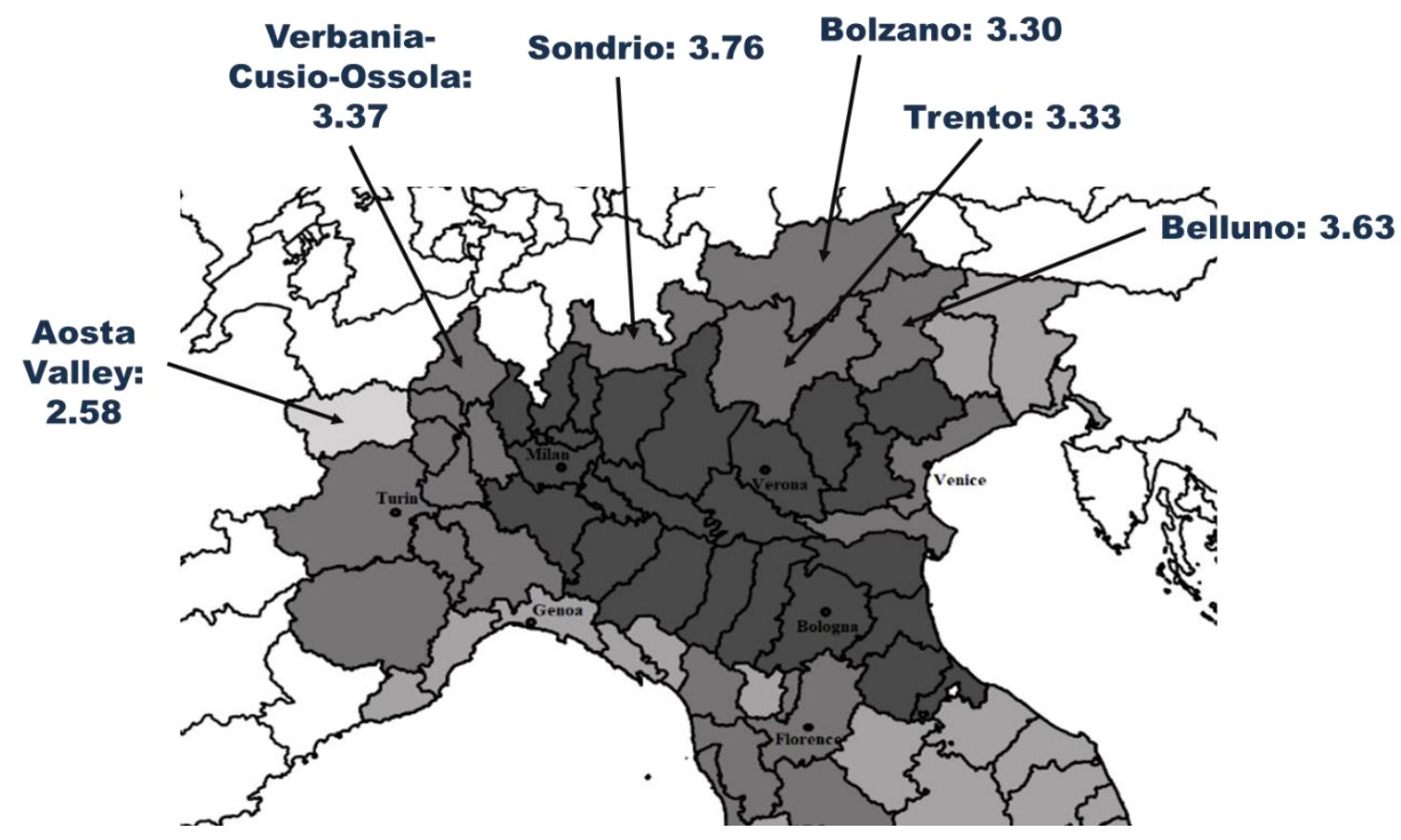

Fig 2. Average rating of Italian Alpine provinces (NUTS3). Source: our elaborations on Musolino (2015)

Tab 2. Average rating of Italian Alpine provinces (NUTS3) and of Italian regions (NUTS3) where they are embedded. Source: our elaborations on Musolino (2015)

\begin{tabular}{|l|l|l|l|}
\hline \multicolumn{1}{|c|}{ PROVINCE } & $\begin{array}{c}\text { AVERAGE } \\
\text { RATING }\end{array}$ & \multicolumn{1}{|c|}{ REGION } & AVERAGE RATING \\
\hline Sondrio & 3.76 & Lombardy & 4.07 \\
\hline Belluno & 3.63 & Veneto & 3.86 \\
\hline Verbano-Cusio-O. & 3.37 & Piedmont & 3.58 \\
\hline Trento & 3.33 & Trentino Alto-Adige & 3.34 \\
\hline Bolzano & 3.30 & Trentino Alto-Adige & 3.34 \\
\hline Aosta & 2.58 & Aosta valley & 2.58 \\
\hline
\end{tabular}




\section{Who has such perception of Alpine provinces?}

The following, intuitive, step in the understanding of such perception of Alpine regions, is to see if, and how, this image changes according to different groups of entrepreneurs, classified by either the type of firm or the type of respondent. That is to say, we wonder whether this image is shared by all types of entrepreneurs or it differs accordingly. In this respect, we have analysed the breakdown of the results presented above by key firms' characteristics, such as size, sector and export orientation; and by some socio-demographic characteristics of the respondents, such as sex, age, and level of education, which are relevant variables according to the theoretical and empirical literature in regional and local economic development ${ }^{9}$.

The statistical technique that was used, i.e., multivariate analysis of variance, enables us to measure the statistical significance of the differences expressed by different groups of entrepreneurs, related to different variables, in the average ratings given to Alpine provinces. For example, as regards to sector: manufacturing firms and services firms; as regards to firm's size: managing small, medium, or big firms; etc. ${ }^{10}$

The results of the multivariate analysis of variance show that there are hardly any statistically significant differences in the ratings of the Alpine provinces given by the different groups of entrepreneurs (Table 3). Entrepreneurs belonging either to manufacturing or to services, managing small, medium, or big firms, being internationalised or not, located in the Southern, central or Northern part of Italy, evaluate the Italian Alpine areas as a potential location for their firms homogeneously. We can say therefore that they share the same image of the Italian Alpine space.

Moreover, the evaluation of these areas does not significantly change according to all three socio-demographic variables taken into consideration (sex, age and education level), again except for a few cases. Young, adult, and old people, and graduates and non-graduates, do not significantly differ in their opinion about the attractiveness of Italian Alpine province.

\footnotetext{
9 The analysis by economic sector, firm size, and export orientation actually can be considered quite relevant, as the theoretical and empirical literature in regional and local economic development has traditionally used these three variables to analyse the basic characteristics of the economic structure of a region, and to define models of regional economic development. For example, the industrial district model, has as a key characteristic the small size of manufacturing firms (see, for example, the works by the founders of the studies on the industrial district model, like Becattini, 1989; Bagnasco, 1977; Brusco, 1982; Garofoli, 1991). Export orientation, moreover, is the key variable for distinguishing firms in terms of degree of internationalisation, which nowadays, in the age of market globalisation, is the key aspect for firms to grow and expand their business. Likewise, the empirical evidence concerning the role played by sex, age, and education on the social and economic behaviour collected in decades of studies and surveys in Italy bring to analyse their potential importance in influencing the image of Alpine areas (see for example, as concerns entrepreneurship, the critical question of the generational change in the family-owned small and mediumsized firms in Italy. Entrepreneurs who leaded the rise of Italian industrial development since 1970s either has already retired or are approaching retirement. They used to have a positive attitude to manual work and to entrepreneurship, and a flexible approach to work organisation, notwithstanding their low level of education. Differently, the younger generations, have a higher level of education and specialisation in fields related to economics and management, but they have a negative attitude to manual work, and are less flexible (Demattè and Corbetta, 1993; Bauer 1997)). This is also the case of the importance of some of these variables stated at a theoretical level (Capello - 2004 - explains well the relevance of human capital in the theories of endogenous growth at the regional level). Lastly, the place of residence (in our case, at the macro-regional scale), can be important, as it can cast light on the so-called locational self-preferences, as seen in other country level studies part of this line of research (Meester, 2004).

${ }^{10}$ For each firm / respondent characteristic, a separate test $F$ was performed for each province. The average rating of that location served as the dependent variable and the firm / respondent characteristic as the (nominal) independent variable. For further information and example about the application of this statistical technique to this line of research, see Meester (2004, ch. 6), and Musolino (2015, ch. 4).
} 
Tab 3. Results of multivariate variance analysis by Italian Alpine province (NUTS3) and firm/respondent characteristic. Source: our own elaborations on data from open questions in the questionnaire survey (225 usable questionnaires)

\begin{tabular}{|l|c|c|c|c|c|c|c|}
\hline PROVINCE & Sector & Firm size & $\begin{array}{c}\text { Export } \\
\text { orientation }\end{array}$ & Macro-region & Sex & Age & Education level \\
\hline Aosta & - & - & - & - & - & - & - \\
\hline Belluno & - & - & - & - & - & - & - \\
\hline Bolzano & - & - & - & $X X$ & - & - & - \\
\hline Sondrio & - & - & - & $X X$ & $X X$ & $X X$ & - \\
\hline Trento & - & - & - & - & - & - & - \\
\hline $\begin{array}{l}\text { Verbano- } \\
\text { Cusio-O. }\end{array}$ & $X X$ & - & - & - & $X X$ & $X X$ & - \\
\hline
\end{tabular}

$X: \operatorname{sig} F<0.05 ; X X: \operatorname{sig} F<0.01$

Sector: manufacturing; services.

Firm size: less than 50 employees; from 50 to 249; equal to or more than 250.

Export orientation (average amount of export on turnover in the last 3 years before the interview): no export; low (from $1 \%$ to $19 \%$ ); moderate (from $20 \%$ to $49 \%$ ); high (from $50 \%$ to $100 \%$ ).

Macro-region: North (Piedmont, Aosta Valley, Lombardy, Trentino Alto-Adige, Veneto, Friuli Venezia Giulia, Liguria, Emilia-Romagna); Centre (Tuscany, Umbria Marche, Lazio); South and Islands (Abruzzo, Molise, Puglia, Basilicata, Campania, Calabria, Sicily, Sardinia).

Age: less than 40 years old; from 40 to 54 ; older than 54

Education level: Junior high school; Senior high school; Bachelor; Msc; PhD/Doctorate.

If the statistical analyses provide clear outcomes as concerns the explanatory relevance of these variables, the analysis of the descriptive statistics for each of the breakdown can anyway give some hints to the interpretation of the findings. This is the case, for example, of the breakdown of the results by economic sector (manufacturing and services firms) (see Table 4). It shows that in all cases, we mean for all Alpine provinces under investigation, ratings by manufacturing firms are always higher than ratings by services firms, even if not statistically significant. This should suggest and remind us the lower level of tertiarisation of the mountain areas, especially regarding business and personal services. Services sector usually tend to agglomerate in the urban and metropolitan areas, as they have to be close to big and densely populated markets. This "constraint" is clearly less important for manufacturing firms, which on the contrary, given the higher fixed costs, might be more attracted by rural and mountain areas as there they can reduce some costs (for example, land and rent costs). Moreover, they can be closer to raw materials and to resources fundamental for their production (for example, water resources, agricultural products, etc.). 
Tab 4. Average rating of the Alpine province by economic sector of entrepreneurs. Source: our elaborations on Musolino (2015)

MANUFACTURING SECTOR

PROVINCE

Sondrio

Belluno

Verbano-Cusio-O.

Trento

Bolzano

Aosta

Alpine provinces
AVERAGE

RATING
SERVICES SECTOR

\section{PROVINCE}

AVERAGE

RATING

3.66

3.77

Sondrio

3.55

3.66

Belluno

3.07

3.48

3.39

Verbano-Cusio-O.

3.16

3.36

Trento

3.12

2.58

Bolzano

3.37
2.56

Aosta

3.19

\section{Explaining the perceived attractiveness of Alpine provinces: a qualitative perspective}

Once we have known the level of perceived attractiveness of the Alpine provinces (compared to other geographical areas), and once we have learnt that this image is shared by all entrepreneurs, the next step is to give an explanation. In order to achieve that, we conducted two different types of qualitative analyses based on (two types of) qualitative data available from the research on the stated locational preferences of Italian entrepreneurs.

The first type of data concerns the responses by entrepreneurs to the open questions included the online questionnaire survey described above, whose objective was to allow respondents to provide a short explanation to the mark assigned to some Italian provinces (randomly extracted by the software $)^{11}$, including also Alpine provinces. Their responses were analysed using the content analysis, in particularly the technique of 'category counts' (Stone et al. 1966, Rositi 1988). The "category counts" technique identifies some keywords in the text of each answer, counts, and defines a certain number of thematic categories based on them ${ }^{12}$, therefore producing, as in our case, quantifiable measures of the open explanations provided by entrepreneurs ${ }^{13}$.

The second type of qualitative data refers to the outcomes of nine direct semi-structured interviews with key informants, experts in attraction of investments and related fields ${ }^{14}$, who were interviewed in order to explain the average ratings of Italian regions and provinces as

\footnotetext{
11 There were two open questions, one for the best-marked and one for the worst-marked province (randomly, that asked the Italian entrepreneurs as follows: "1) "We have noticed that the province of and the province of are among the provinces that you have evaluated as the best hypothetical locations for your firm. Can you shortly explain the reasons why you gave this evaluation, for each of them?" 2) "We ask you the same question as concerns some provinces which, on the contrary, you have evaluated as the worst hypothetical locations for your firm (province of , and province of ). Can you shortly explain the reasons why you gave this evaluation, for each of them?".

12120 respondents answered the open questions, but only 107 gave complete and valid responses. The respondents used 279 keywords. 53 keywords concerned Alpine provinces.

${ }^{13}$ In some cases, we decided to mention direct quotations of the responses provided by the entrepreneurs in the text, in order to corroborate better the results of the content analysis.

14 Interviews were conducted based on an outline between July 2013 and February 2014. People targeted were consultants, representatives of local, regional and national bodies devoted to implementing policies to attract direct investments, representatives of manufacturers' associations, experts on the issue of firms' locational choices, and institutional investors.
} 
emerged from the online questionnaire survey. In other words, they were interviewed in order to investigate in depth the underlying motives that might help to interpret the territorial patterns visible in the maps (see figure 1). The text of these interviews was analysed using the thematic analysis, the technique that serves researchers who are using qualitative information, especially verbal expressions coming from open interviews, in "identifying, analysing, and reporting patterns (themes and sub-themes) within data" (Braun and Clarke 2006, p. 6) ${ }^{15}$.

In this work, of course we focused on the responses by entrepreneurs, and on the parts of the interviews dealing with Alpine areas. The point of view of key informants, in conjunction with the interpretations offered by the entrepreneurs themselves through the open questions included in the questionnaire, provide in depth insights in the explanation of the results about the perceived attractiveness of Italian Alpine areas.

\subsection{Evidence from the open questions submitted to entrepreneurs: the location factors that explain the attractiveness of Alpine provinces}

The figure 3 shows that the factor most frequently mentioned, in positive terms, for Italian Alpine provinces $^{16}$ is, first and foremost, the quality and efficiency of local government, and of their policies to support businesses. The action of the public administration therefore plays a dominant role in the favourable entrepreneurs' evaluation of the Alpine areas as potential locations of their productive activities. This outcome results very interestingly, if we consider that the "lack of institutional settings, and the fragmentation of stakeholders", are usually seen as some of the main problems in the development of mountain regions (Dax, 2020, p. 7).

It is worth quoting some of the entrepreneurs' responses:

"Strong commitment of the provincial government to support businesses"

"Autonomous province, very streamlined and efficient, where bureaucracy is said to be fast"

"Region with special statute, with many breaks for businesses"

"Policies aimed at the preservation of cultural and built heritage. Good reliability of public administration ...."

Interestingly, this theme, which in general is considered a decisive element for the general attractiveness at a territorial and local level ${ }^{17}$, does not assume a great importance in the interpretation of the perceived attractiveness of the best rated Italian provinces. As it emerges in fact from Figure 4, only $11 \%$ of the mentioned refer to the role of public institutions. The fact that the public institutions in the Alpine areas are appreciated so much, in particularly when compared with other areas of the country, therefore enhances the added value for these territories constituted by this location factor ${ }^{18}$.

\footnotetext{
${ }^{15}$ We conducted the thematic analysis analysing the transcripts of the direct interviews. According to this technique, the identification of the relevant key themes depends on the judgement of the researcher, "in terms of whether it captures something important in relation to the overall research question" (Braun and Clarke 2006, p. 10). Direct quotations are frequently used in the text in order to provide clear evidence about the relevance and the prevalence of a theme, as was done in other studies using thematic analysis (see, for example, Delaney et al, 2011; Kitzinger and Wilmott, 2002; Ellis and Kitzinger, 2002).

${ }^{16}$ As said in Section 4, Alpine provinces were given on average ratings major than 3 , which is the intermediate point of the ordinal scale used in the online questionnaire survey.

17 See for example the study on the migration choices of highly skilled people at the provincial level in Italy, by Nifo and Vecchione (2014).

${ }^{18}$ Actually, other analyses highlight the effective role of the government in the Alpine Italian areas. In fact, according to the NUTS2 data by the European Commission, based on the European public administration quality index (Charron and La Puente 2018), the Province of Trento and the Province of Bolzano are the most efficient administrations in Italy, while Aosta Valley in in seventh place.
} 


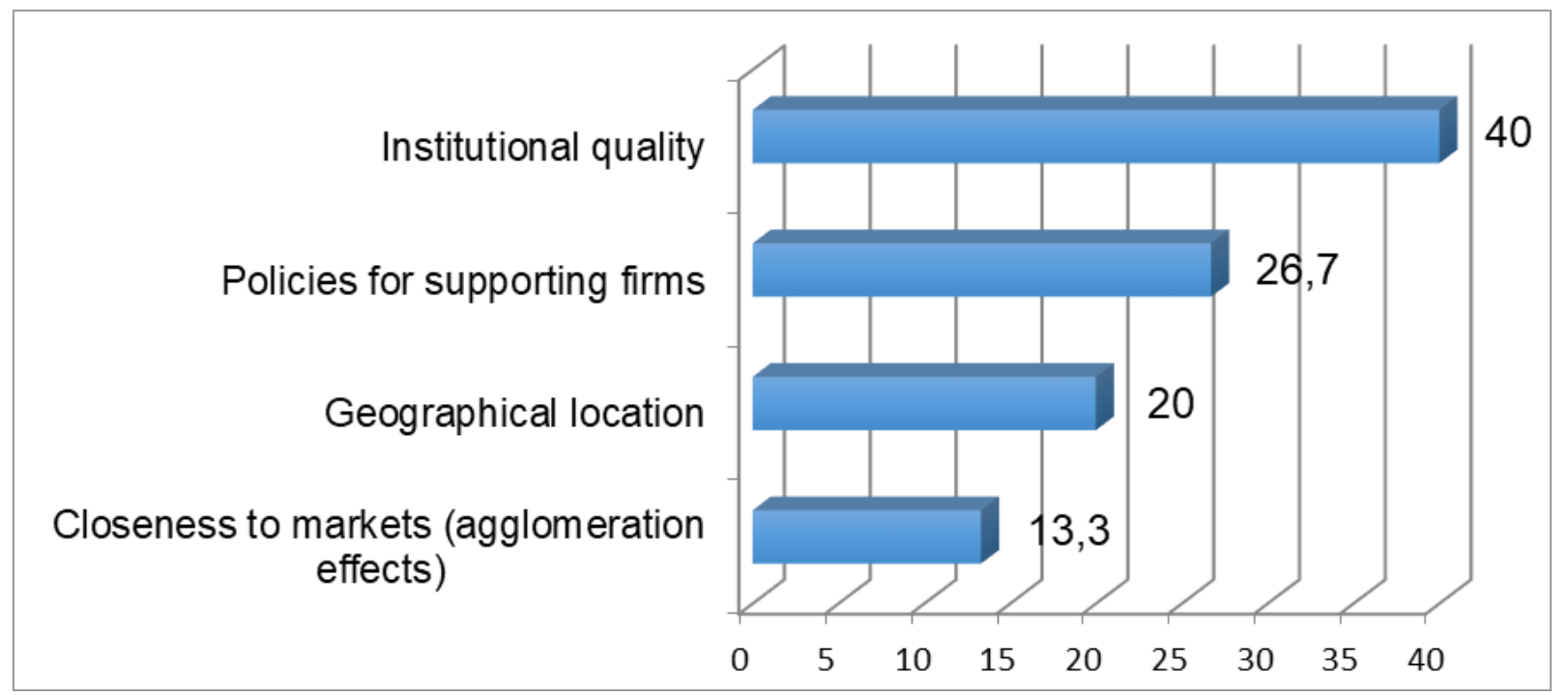

Fig 3. Location factors mentioned for the best-marked Italian Alpine provinces (Percentage composition of the four thematic categories identified from the 53 keywords used by respondents to explain the mark assigned to the best-marked Italian Alpine provinces).

\begin{abstract}
Source: our own elaborations on data from open questions in the questionnaire survey (107 usable questionnaires: 120 respondents answered the open questions, but only 107 gave complete and valid responses. They used 279 keywords: 53 keywords concerned Alpine provinces)
\end{abstract}

A further positive location factor for the attractiveness of mountain areas, emerging from this analysis is the proximity to big neighbouring countries (not only geographical, but also social and cultural). The perception of the locational advantage of the Alpine provinces as border territories is rather relevant. This means that, for example, an Italian company that has to locate a new production unit in Austria or France (even only a commercial one) could choose to settle in a neighbouring territory such as Alto-Adige or Valle d'Aosta, in order to take advantage of the (not only) geographical proximity. Likewise, mirror-like, a French or Austrian company that has to locate a new production unit in Italy could decide to position itself in a border area, characterized by common elements such as linguistic affinity and cultural proximity.

Here it is worthwhile to quote the words of some of the entrepreneurs:

"The proximity to France, climate, values and principles of the local people."

"Close province with cultural heritage, with professional and market opportunities for Austria (Tyrol)."

"A region of limited size, the location near the borders with Switzerland and France could guarantee a strategically interesting positioning." 
Transport infrastructure and services, and logistics

Closeness to suppliers \& markets (agglomeration effects)

Geographical location

Institutional quality and policies for supporting firms

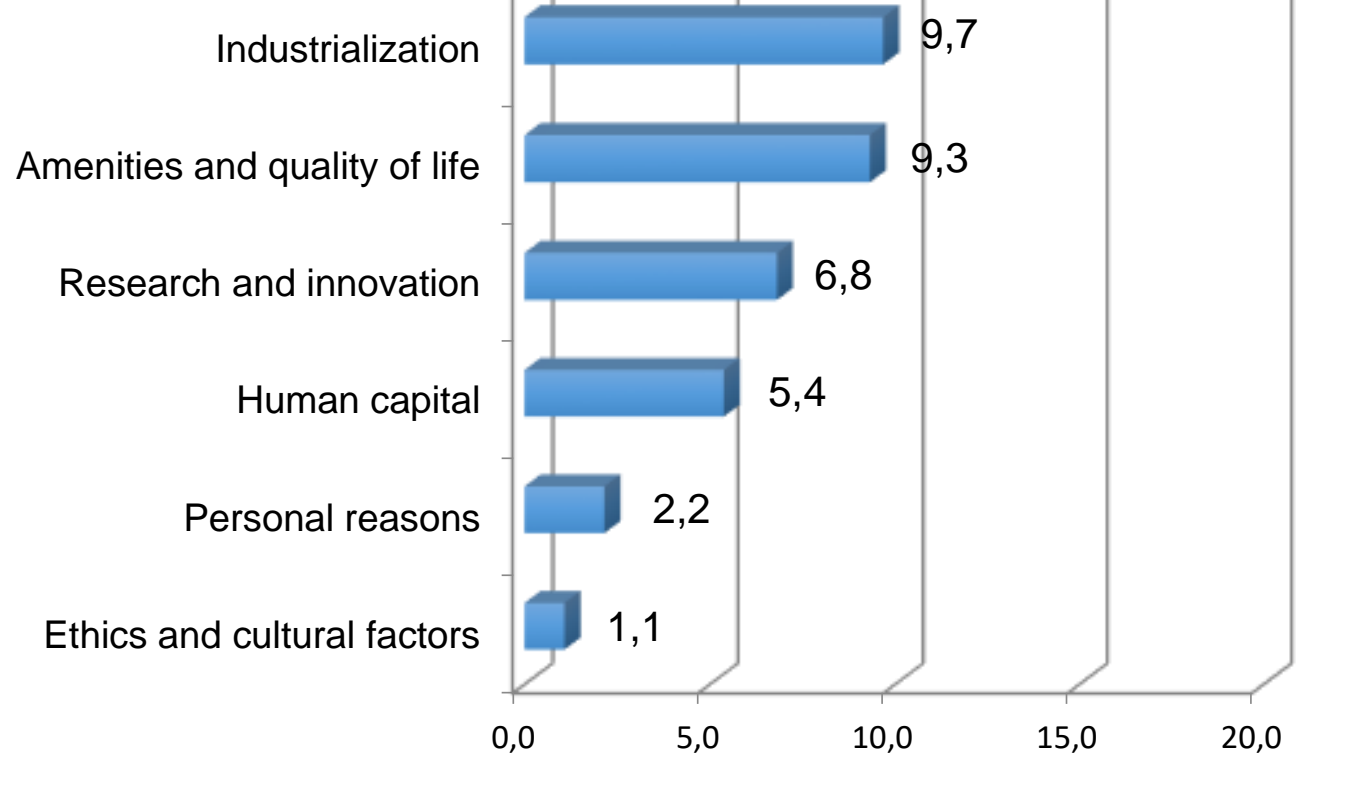

Fig 4. Location factors mentioned for the best-marked Italian provinces (Percentage composition of the ten thematic categories identified from the 279 keywords used by respondents to explain the mark assigned to the bestmarked Italian provinces).

Source: our own elaborations on data from open questions in the questionnaire survey (107 usable questionnaires: 120 respondents answered the open questions, but only 107 gave complete and valid responses. They used 279 keywords)

Geography, therefore, does not only mark the perception of these areas in a negative way, as it happens when we associate it with pure peripherality, that is the distance from the core areas in Central and Northern Italy, as the general result of the web survey would leave one to think. And even as the analysis of relevant indicators, as accessibility at the provincial level in Italy would suggest (see in this respect the clear centre-periphery dichotomy in Northern Italy in figure 5$)^{19}$.

${ }^{19}$ Not by chance, in fact, infrastructure and transport services are considered the main elements to explain the favourable perception enjoyed by the Italian provinces with the highest rating (see Fig. 4). 


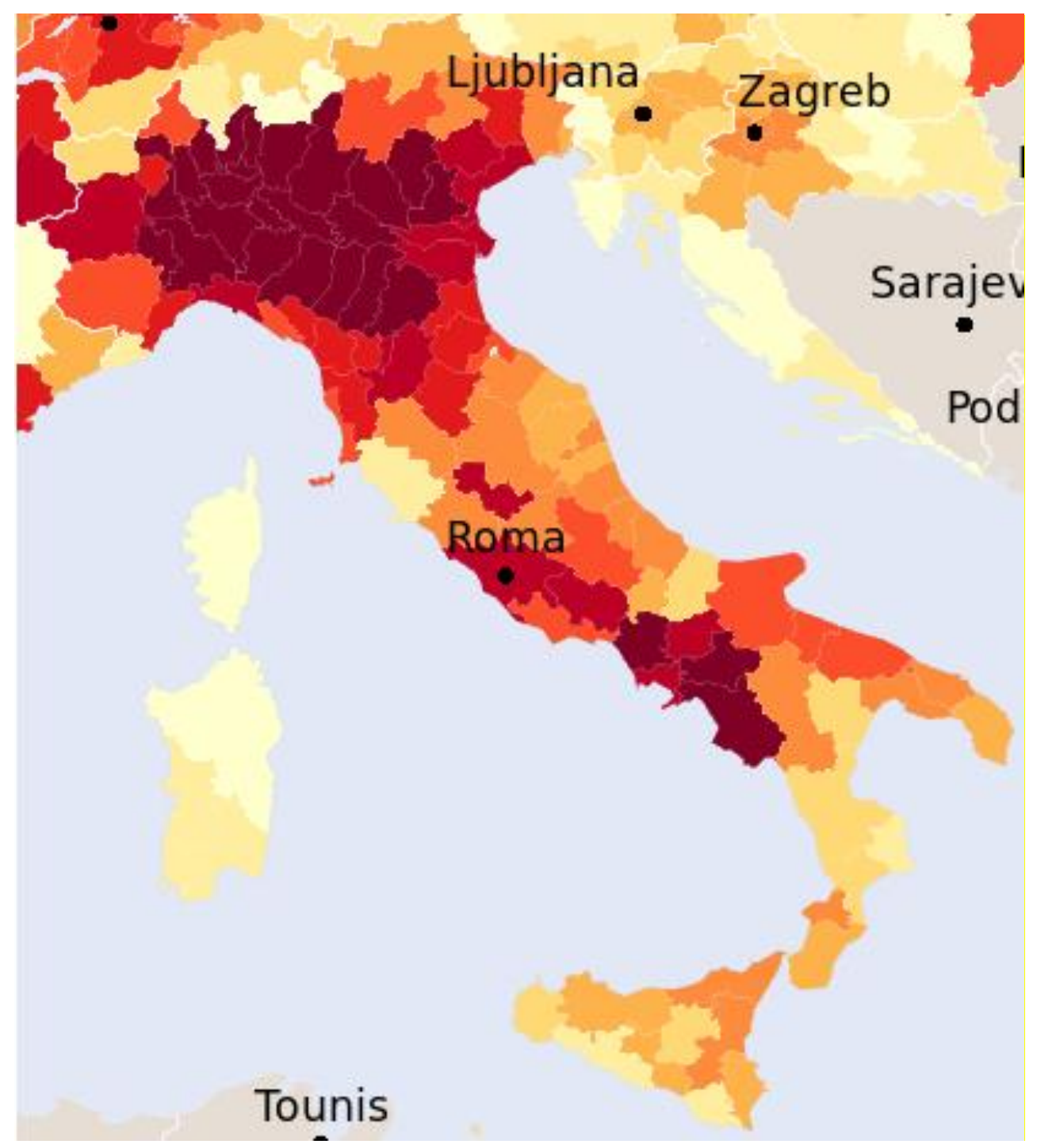

Fig 5. Multimodal potential accessibility in the Italian provinces: Potential of national total population reachable 1 hour in 2011 (in inhab.; mode of transp.: multimodal). Source: based on ESPON Functional indicators tool 2014 (https://wWw.espon.eu/tools-maps/functional-indicators-tool), by UMS RIATE.

The only exception to this image of the Alpine areas as territories acting as 'bridge', as 'gateway' to and from other countries, is represented by the province of Sondrio, in which the geographical proximity to neighbouring foreign territories is less felt, to facing a stronger perception of proximity to important central territories, such as the province of Milan. In this sense, the "gravitational force" of the Milanese economy certainly plays an important role, together perhaps with the lack of large infrastructural axes connected with neighbouring countries, as in the case of Aosta, Trento and Bolzano.

The last significant element detected by the content analysis, as seen in Figure 3 , is the potential of the Alpine area market. This is a rather surprising, counter-intuitive result, if we consider that the mountain areas are characterized by multiple physical and economic constraints, including the presence on the territory of a fragmented and in any case not so big market of goods and services (at least, if compared with the main urban agglomerations). This element, apparently considered as a constraint, could be in fact a competitive advantage, if viewed from another aspect. The low presence of productive settlements in fact entails an insufficient supply and a limited competition, which can encourage the entry into the market of new companies.

According to some of the open responses provided by entrepreneurs, in fact: 
"Because it represents a market in which the company would have the possibility of covering a gap on the supply side."

"Because the province of Belluno represents a market in possible expansion."

\subsection{Evidence from the point of view of key informants: the key role of bordering location and of institutions}

Key informants focused their attention on the explanatory role of two of the location factors, already highlighted in the content analysis: the "dual value" of the geographical location of these provinces, and the quality of their public institutions.

The first great explanatory question that emerges from the thematic analysis is that of the "dual value" of the geographical location of these provinces: on the one hand, the disadvantages linked to their peripherality in the regional and macro-regional Italian context; but on the other hand, the advantages associated to proximity, not only geographical, with other countries.

Key informants went in depth in the understanding of this question. They discussed first why the location of the Alpine provinces, peripheral in a national context, constitutes a locational disadvantage for productive investments compared to other, more central, areas of the country.

"The central-periphery issue is still important, typically when you are peripheral. Access to certain services, to certain resources ... you have much more difficulty having it. You can easily locate managerial resources of a certain level in Milan, but if you have to start sending them either to Pordenone or to Bolzano, it's still a penalizing factor ... "

"... even within Lombardy, in a certain sense Sondrio or Mantua are more peripheral than Florence or Padua, because they too are peripheral compared to the most attractive centre, so why going to Sondrio if I can go to Milan .... Obviously, for some functions I cannot go to Milan, but if for these functions I can go to Piacenza rather than Sondrio, I prefer to go to Piacenza, which is better served, maybe lower costs, wider labour market ... and so on ..."

".... where there are important companies, doing a business, expanding is easier, you can find everything in some ways ... Piedmont, for example, for me is a very good region, which is not so far from the others. Trentino and Friuli are more mountain regions, they live off something else ..."

Secondly, they indeed noted that a location factor does not always have a totally negative or positive connotation. Sometimes, a weak point can turn into a strong point for a place, and vice versa. Depending on the subjective perspective (in this case, by entrepreneurs), it could be that an element identified by most people as a point of territorial weakness can be a competitive advantage. As emerged from the content analysis, even in the thematic analysis a 'reverted' concept of peripherality of the mountain territories of the Alps have in fact sprung up.

Key informants explained how, changing perspective, areas located at the end of the national territory could be seen as "precious" bordering areas with other countries for businesses that aim to internationalize. Foreign companies can in fact decide to invest in a bordering country, locating first in territories closer and similar to them, taking advantage of several kind of affinities (linguistic, cultural, etc.), and then extending to the rest of the territory of the destination country of the investment. For example, border areas such as Trentino Alto-Adige and Valle d'Aosta have in common with neighbouring foreign territories, history, traditions, customs and the use of the same (or similar) languages. Think for example of Alto Adige and German-speaking countries, such as Austria and Germany.

"... Some, not all, the bigger ones go to Milan anyway, but there are companies that make a first attempt on the South Tyrol market and, if it works, they go on farther, like in the Veneto."

"It starts in South Tyrol, same language. Then from there ... there is a second location in Bolzano, then again within this region we move to Bressanone, Vipiteno, then maybe 
we go to Trento and stretch towards Veneto, Treviso, Verona and then we extend into the rest of the Italian territory ..."

"... some German companies, for example, start to invest in Alto-Adige for language reasons, and then from there they try to spread in the Italian territory ..."

The same element of bilingualism, as an officially recognized aspect, at other times it could even create an obvious, as well as difficult to reproduce, locational advantage.

"... some companies, including Austrian ones, invest or constitute their Italian offices in Trentino Alto-Adige. They constitute it in South Tyrol because you can also do the deed of incorporation in German - which translated, obviously also applies in Italy. Moreover, it is perhaps advantageous for these companies to explore the market with human resources who speak the same language. After that if it works, they also go to other regions."

This "dual" perception of the peripheral character of mountain areas suggests, according to key informants, that there is an underestimation of the actual attractiveness of mountain areas. The fact that elements that the generality of the subjects tends to consider as critical factors of the territory (geographical location) can actually be re-qualified and exploited to draw advantages from it, could suggest that the actual level of attractiveness of the territory is higher than that estimated in the average image of the majority of the actors.

In addition to the theme of geographical location, which resulted to be fundamental to understand the evaluation of the attractiveness of the Alpine provinces, even key informants paid a remarkable attention to the role of public institutions. In addition to being part of regions that obviously enjoy good administration (Sondrio, In Lombardy; Belluno in Veneto), it is in particular the issue of the Special Statute Regions to be raised by them. In fact, these types of regions have the power to implement policies and actions that are particularly relevant in support of attractiveness, for all productive sectors, in the same way as what happens for example in federal countries such as the United States:

"It is a region with a special status, and has a whole series of major autonomies .... it can do things that other regions cannot do ... these are things that Sardinia can do, which Friuli Venezia-Giulia, Sicily or Trentino can do ... South Tyrol"

"We better say that the Region Valle d'Aosta, thanks to greater autonomy, can offer certain companies the conditions that Piedmont is unable to offer...."

".... in a rather indistinct manner, there have been situations in which entrepreneurs have found areas where to build new plants, new warehouses, new offices at very competitive prices, not to mention with almost free areas set aside ... the Autonomous Region can offer that.... it is a widespread practice, for example in the United States ... the States, within the parameters that they must respect to contribute to the federal budget, have great freedom of manoeuvre.... there are States that have extremely aggressive policies in the field of attracting investments where for example they receive free areas for large industrial settlements, they have very aggressive tax policies, tax exemption of profits, lack of tax payment on profits that may be reinvested there, incentive policies.... they go a little beyond the incentive that can be considered by the company as a "hit and run" strategy.... "

\subsection{Aosta and the role of accessibility}

A final and special reflection, coming from outcomes of the content analysis and the thematic analysis, concerns the case of Aosta. This province in fact, as we have seen in section 4, receives a rather negative evaluation in terms of perceived attractiveness (less than 3 ), quite lower than the average of the Alpine provinces. The few answers by entrepreneurs to open questions collected on the case of Aosta, as one of the worst-marked provinces, do not allow producing a categorization and a count of the keywords frequency. However, even in this case, it is worth quoting some of the answers obtained, which focus on the isolation, remoteness and poor accessibility of this province: 
"For his isolation from the rest of Italy"

"Difficult transport"

"Far from customers and suppliers"

Aosta, more than other Alpine areas, despite its location on the border, and despite the Special Statute, seems to suffer more than other Alpine provinces, particularly the low level of transport accessibility, as Figure 5, mapping transport accessibility at the NUTS3 level show very well. As also underlined by key informants:

"The low score of the Valle d'Aosta, compared to the northern regions, amazed me ... If we talk about locational preferences, that is how entrepreneurs evaluate and perceive the attractiveness of the regions, I say this because especially in Piedmont, Valle d'Aosta is considered a particularly attractive and particularly friendly region for companies, including Italian ones,.... so many Piedmontese companies have, as long as they do $10 \mathrm{~km}$, a series of benefits, favourable treatments, that an autonomous region, that can treat certain materials in a certain way more than an ordinary region, can afford to, .. this amazes me a little .... the question of accessibility is likely to be important .."

\section{Conclusions and policy implications}

In conclusion, after these analyses, we can state that it is not said that being mountain areas are unattractive itself, because of their intrinsic characteristics in terms of challenging physical geography. Indeed, one, at a first impression, one would think to them as harsh places for investment, "viewing them purely in terms of their topography (altitude above sea level and slope inclination) .... which often leads to associations with harsh, cold climates and snowtopped peaks..." (Dax, 2020, p.1).

The findings of the analyses conducted above instead make it clear that Alpine areas, although their specific geographical characteristics and the lower level of accessibility, are not so unattractive compared to other areas in Italy, as places where to potentially locate their investments. This image of the Alpine areas in Italy is shared by all kinds of entrepreneurs, so it is rather robust. However, firms are aware of the potential advantages deriving from the location in the mountain regions. This means that market driving exogenous investments can be actually thought as potential factors of development, together with endogenous, locally established, factors, without taking for granted that exogenous development means always dependent statedriven development, based on continued subsidies coming from the central government (Lowe et al, 1998).

The attractiveness of the six Alpine provinces can be explained by four factors:

- The role of the public local institutions (local government), which on the one hand have got a high quality (bureaucracy), and on the other hand make effectively policies for local development (supporting firms, not only financially). This concerns in particularly the provinces with autonomous governments.

- The proximity to big and developed bordering countries, like Germany and France, only geographic, but also linguistic and cultural. Again, Bolzano is mentioned as the 'gateway' for the investments coming from the German speaking countries, together with Aosta, concerning France.

- The proximity to the Padana Region, the most developed and densely inhabited macroregion in Italy, which is approximately covered by the territory of three administrative regions: Lombardy, Veneto and Piedmont. Actually, three Alpine provinces are part of these administrative regions, respectively Sondrio, Belluno, and Verbania-Cusio-Ossola, and, as we saw, this is something that probably affect their image (to a certain extent that they 'live on reflected light').

- Last but not least, the potential in terms of market areas. In fact, even if small, these areas have a level of income and wealth (potential demand) rather high, so that some 
entrepreneurs even talk about these areas (for example, Belluno) as potential markets where to locate their business.

Yet, the question of peripherality and low accessibility plays a role in the perception of entrepreneurs, as explained by key informants, but it is not such a 'constraint' that lower remarkably the level of perceived attractiveness of these areas. The only exception is Aosta, where the question of the low accessibility, clearly highlighted by the EU data, is likely to explain why entrepreneurs assign such a lower rating to this province, although its locational advantages represented by proximity to France and the high level of economic development.

Ultimately, the evidence collected in this work goes a long way supporting the idea that the attractiveness of mountain areas, in positive and negative terms, is not explained by "soft factors", as happens in the case of attractiveness of mountain areas for tourism (see Baldazzi et al 2016), but mostly by the so-called "hard factors" (geographical location, taxation policies, economic development, accessibility, etc.). These factors play a significant explanatory role also in the attractiveness of other types of regions and places, as seen in Section 2.

Policy implications are intuitive and clear. Improving accessibility remains a fundamental issue of development strategies for these areas, in particular when they can strengthen their connection with important bordering regions and countries. This does not mean investing necessarily in new "hard infrastructure"; but, at least improving mobility and even connectivity with the outer areas (Bock, 2016). However, this also means improving cooperation with the foreign bordering regions (not only 'hard', but also 'soft' interconnections), and realising targeted territorial marketing policies, in order to emphasize and promote the common cultural and linguistic characteristics.

Moreover, policies for investment attraction should be more active, not only using tax relief but also supporting, in a wider sense of entrepreneurs intentioned to invest in these areas. Only improving policies for investment attraction the low level of exogenous investments seen in Section 3 can be raised, diversifying and making stronger the regional economic structure. Lastly, these policies should be part of the integrated approaches (multi-sectoral and multi-level of governance) increasingly adopted by regional and local governments, following the experiences of the LEADER and CLLD (Community-led Development Scheme) (Dax, 2020).

\section{Acknowledgements}

We are very grateful to the two reviewers for their precious comments. We are also very grateful to Dr. Thomas Philipp Streifeneder, who read the first version of the paper, and gave us a lot of important suggestions.

Academic references

[1] Akimowicz, M., Vyn, R. J., Cummings, H. \& Landman, K. (2018). An introduction to mixed methods research in agricultural economics: The example of farm investment in Ontario's Greenbelt, Canada. Journal of Rural Studies 61, 162-174. DOI: 10.1016/j.jrurstud.2018.04.012.

[2] Annoni, P. \& Dijkstra, L. (2013). EU Regional Competitiveness Index. Luxembourg: Publication Office of EU.

[3] Bagnasco, A. (1977). Tre Italie: La problematica territoriale dello sviluppo italiano. Bologna: II Mulino.

[4] Baldazzi, B., Morricone, M., Talucci, V. \& Ungaro, P. (2016). L'impatto turistico nelle regioni italiane: un indicatore composito di attrattività e sostenibilità turistica. In: Mazzola, F., Nisticò, R., eds., Le Regioni Europee. Politiche per la coesione e strategie per la competitività. Milan: Francoangeli. 
[5] Baldwin, R (2016). The Great Convergence: Information Technology and the New Globalization. Cambridge, MA: Belknap Press of Harvard University Press.

[6] Bauer, M. (1997). Tra impresa e famiglia. Trasmissione e successione nelle piccole e medie imprese. Roma: NIS.

[7] Becattini, G. (1989). Sectors and/or districts: Some remarks on the conceptual foundations of industrial economics. In Goodman, E., Bamford, J. \& Saynor, P., eds., Small firms and industrial districts in Italy (pp. 125-135). London: Routledge.

[8] Bock, B. (2016). Rural Marginalisation and the Role of Social Innovation; A Turn Towards Nexogenous Development and Rural Reconnection. Sociologia Ruralis 56(4), 552-573. DOI: $10.1111 /$ soru.12119.

[9] Bosworth, G. \& Atterton, J. (2012). Entrepreneurial in-migration and neo-endogenous rural development. Rural Sociology 77(2), 254-279. DOI: 10.1111/j.1549-0831.2012.00079.x.

[10] Brusco, S. (1982). The Emilian model: Productive decentralisation and social integration. Cambridge Journal of Economics 6(2), 167-184. DOI: 10.1093/oxfordjournals.cje.a035506.

[11] Barba Navaretti, G., Basile, R., Benfratello, L. \& Castellani, D. (2009). II Mezzogiorno e gli investimenti diretti esteri. Torino: Centro Studi Luca D'Agliano.

[12] Bentivogli, C., Cherubini, L. \& luzzolino, G. (2015). L'attrattività dei territori: i fattori di contesto. Politica Economica 1, 3-26.

[13] Bloningen, B. (2005). A Review of the Empirical Literature on FDI Determinants. Atlantic Economic Journal 33, 383-403. DOI: 10.1007/s11293-005-2868-9.

[14] Camagni, R. (2009). Territorial capital and regional development. In Capello, R. \& Nijkamp, P., eds., Handbook of regional growth and development theories (pp. 118-132), Cheltenham (UK), Edward Elgar.

[15] Camagni, R. (2002). On the concept of territorial competitiveness: sound or misleading? Urban Studies 39(13), 2395-2411.

[16] Capello, R. (2004). Economia regionale. Bologna: II Mulino.

[17] Capello, R. \& Dentinho, T. (2012). Globalization Trends and Regional Development Dynamics of FDI and Human Capital Flows. Cheltenham: Edward Elgar.

[18] Capello, R., Fratesi, U. \& Resmini, L. (2011). Globalization and Regional Growth in Europe. Past Trends and Future Scenarios. Berlin: Springer-Verlag.

[19] Casi, L. \& Resmini, L. (2010). Evidence on the determinants of foreign direct investment: The case of EU regions. Eastern Journal of European Studies 1(2), 93-118.

[20] Cavallo, L., D’Elia, M., Petrei, F. \& Santoro, M. T. (2018). II turismo volano dello sviluppo delle aree interne? [unpublished conference paper], retrieved from https://aisre.it/images/aisre/5b979ff990ebb7.68253445/20180911_Cavallo-D_Elia-PetreiSantoro_Aree_Interne.pdf.

[21] Charron, N. \& Lapuente, V. (2018). Quality of Government in EU Regions: Spatial and Temporal Patterns [QOG working paper Series 2018:2]. University of Gothenburg.

[22] Daniele, V. \& Marani, U. (2011). Organized crime, the quality of local institutions and FDI in Italy: A panel data analysis. European Journal of Political Economy 27(1), 132-142. DOI: 10.1016/j.ejpoleco.2010.04.003.

[23] Dax, T. (2020). Neoendogenous Rural Development in Mountain Areas. In Cejudo, E. \& Navarro, F., eds., Neoendogenous Development in European Rural Areas (pp. 3-20). Cham: Springer.

[24] Demattè, C. \& Corbetta, G. (1993). I processi di transizione delle imprese familiari [working paper]. Milano: Università Commerciale L.Bocconi. 
[25] De Rubertis, S. (2014). Territorializzazione ed europeizzazione delle politiche di sviluppo. In D'Amico, M. \& De Rubertis, S., eds., Unione Europea e prove di ente intermedio in Italia (pp. 13-29). Soveria Mannelli: Rubettino.

[26] Ezmale, S. (2012). Strategies for enhancing attractiveness of the cities in Letgale Region. European Integration Studies 6, 121-127. DOI: 10.5755/j01.eis.0.6.1601.

[27] Fratesi, U. \& Senn, L., eds. (2009). Growth and Innovation of Competitive regions. The role of Internal and External connections. Heidelberg: Springer-Verlag.

[28] Freeman, R. B. (2006). People Flows in Globalization. Journal of Economic Perspective 20(2), 145-170. DOI: 10.1257/jep.20.2.145.

[29] Garofoli, G. (1991). Modelli locali di sviluppo. Milano: Franco Angeli.

[30] Greene, J. C., Caracelli, V. J. \& Graham, W. F. (1989). Toward a Conceptual Framework for Mixed-Method Evaluation Designs. Educational Evaluation and Policy Analysis 11(3), 255-274. DOI: 10.3102/01623737011003255.

[31] Lowe, P., Murdoch, J. \& Ward, N. (1995). Networks in Rural Development: Beyond Exogenous and Endogenous Models. In Ploeg, van der J. D. \& Dijk, van G., eds., Beyond Modernization The impact of Endogenous Rural Development (pp. 87-106). Assen: Van Gorcum.

[32] Lowe, P., Ray, C., Ward, N., Wood, D. \& Woodward, R. (1998). Participation in Rural Development: $A$ Review of European Experience [research report]. University of Newcastle.

[33] Martin, R. (2006). A Study on the Factors of Regional Competitiveness [draft final report]. Brussel: The European Commission Directorate-General Regional Policy.

[34] Markusen, J. R. \& Venables, A. J. (1999). Foreign direct investment as a catalyst for industrial development. European Economic Review 43(2), 335-356. DOI: 10.1016/S00142921(98)00048-8.

[35] McNally, S. (2001). Farm Diversification in England and Wales. What can we Learn from the Farm Business Survey? Journal of Rural Studies 17(2), 247-257. DOI: 10.1016/S07430167(00)00050-4.

[36] Meester, W. J. (2004). Locational preferences of entrepreneurs: stated preferences in The Netherlands and Germany. Heidelberg: Physica-Verlag.

[37] Meester, W J. \& Pellenbarg, P. H. (2006). The spatial preference map of Dutch entrepreneurs: subjective rating of locations, 1983, 1993 and 2003. Tijdschrift voor Economische en Sociale Geografie 97(4), 364-376. DOI: 10.1111/j.14679663.2006.00349.x.

[38] Musolino, D. (2015). Stated locational preferences of entrepreneurs in Italy. The patterns, the characteristics and the explanatory factors of the Italian entrepreneurs' mental maps [PhD Thesis]. University of Groningen.

[39] Musolino, D. (2018). Characteristics and effects of twin cities integration: The case of Reggio Calabria and Messina, 'walled cities' in Southern Italy. Regional Science: Policy and Practice 10(4), 315-334. DOI: 10.1111/rsp3.12128.

[40] Musolino, D. (2018). The north-south divide in Italy: Reality or perception? European Spatial Research and Policy 25(1), 29-53. DOI: 10.18778/1231-1952.25.1.03.

[41] Musolino, D., Meester, W. J., Pellenbarg, P. H. (2020). The mental maps of Italian, German and Dutch entrepreneurs: a comparative perspective. The Annals of Regional Science, 64, pp. 595-613.

[42] Musolino, G. \& Vitetta, A. (2011). Short-term forecasting in road evacuation: Calibration of a travel time function. WIT Transaction of the Built Environment 116, 615-626. DOI: $10.2495 /$ UT110521. 
[43] Neumeier, S. (2017). So-cial innovation in rural development: identifying the key factors of success. The Geographical Journal 183(1), 34-46. DOI: 10.1111/geoj.12180.

[44] Nifo, A. \& Vecchione, G. (2014). Do Institutions Play a Role in Skilled Migration? The Case of Italy. Regional Studies 48(10), 1628-1649. DOI: 10.1080/00343404.2013.835799.

[45] North, D. \& Smallbone, D. (2000). The Innovativeness and Growth of Rural SMEs during the 1990s. Regional Studies 34(2), 145-157. DOI: 10.1080/00343400050006069.

[46] Padovani, R. \& Provenzano, G. (2015). La convergenza «interrotta». II Mezzogiorno del 1951-1992: dinamiche, trasformazioni, politiche. In Padovani, R., ed., La dinamica economica del Mezzogiorno (pp. 31-40). Bologna: Il Mulino.

[47] Pellenbarg, P. H. (1985). Bedrijfsrelokatie en ruimtelijke kognitie; onderzoekingen naar bedrijfsverplaatsingprocessen en de subjektieve waardering van vestigingsplaatsen door ondernemers in Nederland [PhD Thesis]. Rijksuniversiteit Groningen.

[48] Pellenbarg, P. H. (2012). De mental map van de Nederlandse ondernemer: 1983-19932003-2012. Groningen: Rijksuniversiteit Groningen.

[49] Pfeifer, C., Jongeneel, R., Sonneveld, M. P. W. \& Stoorvogel, J. J. (2009). Landscape Properties as Drivers for Farm Diversification: A Dutch Case Study. Land Use Policy 26(4), 1106-1115. DOI: 10.1016/j.landusepol.2009.01.007.

[50] Phelps, N. A. \& Raines, P. (2003). The New Competition for Inward Investment: Companies, Institutions and Territorial Development. Cheltenham: Edward Elgar.

[51] Ray, C. (2006). Neo-endogenous rural development in the EU. In Cloke, P., Marsden, P. \& Mooney, P., eds., Handbook of Rural Studies (pp. 278-291). Thousand Oaks: Sage. DOI: $10.4135 / 9781848608016$.

[52] Resmini, L. (2014). Patterns of FDI in Southern European Periphery [unpublished paper]. Retrieved from http://www-sre.wu.ac.at/ersa/ersaconfs/ersa14/e140826aFinal00543.pdf.

[53] Rixen, C., Teich, M., Lardelli, C., Gallati, D., Pohl, M., Pütz, M. \& Bebi, P. (2011). Winter Tourism and Climate Change in the Alps: An Assessment of Resource Consumption, Snow Reliability, and Future Snowmaking Potential. Mountain Research and Development, 31(3), 229-236. DOI: 10.1659/MRD-JOURNAL-D-10-00112.1.

[54] Santangelo, G. D. (2004). FDI and Local Capabilities in Peripheral Regions: The Etna Valley Case. Transnational Corporations 13(1), 73-108.

[55] Sedlacek, S., Kurka, B. \& Maier, G. (2009). Regional identity: a key to overcome structural weaknesses in peripheral rural regions? European Countryside 1(4), 180-201. DOI: 10.2478/v10091-009-0015-3.

[56] Servidio, G. (2015). Industria meridionale e politiche di incentivazione: storia di un progressivo disimpegno. In Padovani, R., ed., La dinamica economica del Mezzogiorno (pp. 221-270). Bologna: II Mulino.

[57] Silvetti, A. (2017). Attrattivita' delle aree montane per gli investimenti produttivi: il caso delle aree alpine. Tesi di Laurea (M.Sc. Thesis), Università della Valle d'Aosta, Aosta, Italy (Supervisor: Prof. Dario Musolino).

[58] Spilanis, I., Kondili, J. \& Gryllaki, S. (2003). Measuring the attractiveness of small islands. A tool for sustainability [unpublished paper]. Retrieved from http://www1.aegean.gr/lid/internet/elliniki_ekdosi/Dimosieuseis/Malta_paper.pdf.

[59] Spilková, J. (2007). Foreign firms and the perception of regions in the Czech Republic: a statistical examination. Tijdschrift voor Economische en Sociale Geografie 98(2), 260 275. DOI: 10.1111/j.1467-9663.2007.00395.x.

[60] van der Ploeg, J. D. \& Roep, D. (2003). Multifunctionality and Rural Development: the Actual Situation in Europe. In van Huylenbroeck, G. \& Durand, G., eds., Multifunctional 
Agriculture. A New Paradigm for European Agriculture and Rural Development (pp. 37-54). Aldershot: Ashgate.

[61] Villaverde, J. \& Maza, A. (2012). Foreign direct investment in Spain: Regional distribution and determinants. International Business Review 21(4), 722-733. DOI: 10.1016/j.ibusrev.2011.08.004.

[62] Ward, N., Atterton, J., Tae-Yeon, K., Lowe, P., Phillipson, J. \& Thompson, N. (2005). Universities, the Knowledge Economy and 'Neo-endogenous' Rural Development [working paper]. Newcastle University.

[63] Ward, N. \& McNicholas, K. (1998). Reconfiguring Rural Development in the UK: Objective $5 \mathrm{~b}$ and the New Rural Governance. Journal of Rural Studies 14(1), 27-39. DOI: 10.1016/S0743-0167(97)00045-4.

Other sources

[64] FMI (2017). Rapporto Montagne Italia 2017. Soveria Mannelli: Rubbettino Editore.

[65] Fondazione Nord-Est (2002). Nord-Est e Mezzogiorno. Tra nuove relazioni e vecchi stereotipi. FORMEZ, Roma: Donzelli Editore.

[66] GPF\&ISPO (2005). L'immagine del Mezzogiorno d'Italia. Esiti della rilevazione condotta nel 2004 presso la Business Community di 10 Paesi esteri e del Centro Nord Italia.

[67] Istat (2018a). Indicatori demografici. Stime per l'anno 2017. Statistiche Report, 8 Febbraio.

[68] Istat (2018b). Conti Economici Territoriali. Anno 2017. Statistiche Report, 13 Dicembre.

[69] Politecnico di Milano, Università Cattolica del Sacro Cuore, Università Commerciale Luigi Bocconi, Università degli studi di Milano, Università degli studi di Milano Bicocca, Università IULM. 2010, Osservatorio marketing territoriale. $1^{\circ}$ Rapporto di Competitività ed Attrattività della città di Milano, Milano, Camera di Commercio di Milano e Comune di Milano.

[70] Spiekermann \& Wegener Urban and Regional Research (S\&W) (2007). Update of Selected Potential Accessibility Indicators. Final Report, February. Available at: https://www.espon.eu/sites/default/files/attachments/espon_accessibility_update_2006_fr_ 070207.pdf

[71] UNCTAD (2017). Trade and Development Report 2017. New York and Geneva: United Nations.

[72] UNCTAD (2018). World Investment Report: Annex Tables (https://unctad.org/en/Pages/DIAE/World\%20Investment\%20Report/Annex-Tables.aspx). 